\title{
Late Cretaceous Elopomorpha (Actinopterygii: Teleostei) from the Mahajanga Basin of Madagascar and impacts on paleobiogeography
}

\author{
Summer A. Ostrowski
}

\begin{abstract}
The Upper Cretaceous deposits of Madagascar have produced a rich terrestrial vertebrate fauna. Studies of Madagascar's endemic fossils and recent fauna have led to multiple hypotheses surrounding the origin of these clades on the island following its complete isolation $88 \mathrm{~m}$.y.a. This report is the first published description of several representatives of fossil Elopomorpha (Teleostei) from the Late Cretaceous of Madagascar. Elopomorphs are primarily marine fishes and one of the most morphologically diverse groups within teleosts. Fragmentary fossil elopomorph elements often consist of tooth plates and vertebrae. The tooth plates and dentary reported here are diagnostic and identifiable to the generic classification of Albula, Egertonia, and Paralbula. The vertebrae are numerous and morphologically variable, which indicates the abundance and importance of elopomorphs in the coastal environment of Madagascar during the Late Cretaceous. Most Cretaceous elopomorphs are from localities in the Northern Hemisphere. While several species of Cretaceous elopomorphs are also found in the Southern Hemisphere, there are not as many in number or kind. These Madagascar fossils represent the oldest Albula and Paralbula fossils recorded from Gondwana, increasing their known spatial range. The Egertonia material described here represents one of the earliest occurrences of the genus, adding to its record during the Cretaceous of Gondwana. The presence of these fishes supports a more global distribution of these genera during the Late Cretaceous and a higher diversity of Elopomorpha in the Southern Hemisphere during the Mesozoic than previously documented.
\end{abstract}

Summer A. Ostrowski. Department of Biological Sciences, University of Wisconsin-Parkside, Kenosha, Wisconsin, USA. summer.ostrowski@uwp.edu

Keywords: Gondwana; Cretaceous; Madagascar; Albula; Egertonia; Paralbula; paleobiogeography

Submission: 15 January 2021. Acceptance: 4 September 2021.

Ostrowski, Summer A. 2021. Late Cretaceous Elopomorpha (Actinopterygii: Teleostei) from the Mahajanga Basin of Madagascar and impacts on paleobiogeography. Palaeontologia Electronica, 24(3):a31. https://doi.org/10.26879/1151

palaeo-electronica.org/content/2021/3446-madagascar-elopomorpha

Copyright: October 2021 Society of Vertebrate Paleontology.

This is an open access article distributed under the terms of the Creative Commons Attribution License, which permits unrestricted use, distribution, and reproduction in any medium, provided the original author and source are credited.

creativecommons.org/licenses/by/4.0 


\section{INTRODUCTION}

Elopomorpha is one of most morphologically diverse groups of teleosts and contains Elopiformes (tarpons), Albuliformes (bonefishes), Anguilliformes (true eels), and Notacanthiformes (halosaurs and spiny eels). This group of fishes has a deep-reaching fossil record back into the Upper Jurassic of Europe (Arratia, 2000; Rauhut et al., 2017). Elopomorpha are monophyletic, with leptocephalus larva as a notable synapomorphy (Greenwood et al., 1966; Arratia, 1997; Wiley and Johnson, 2010) along with other morphological and molecular traits (Faircloth et al., 2013; Chen et al., 2014; Dornburg et al., 2015; Betancur-R et al., 2017). Elopomorpha are mostly represented in Laurasian fossil localities throughout the Mesozoic and Cenozoic (Estes, 1969; Applegate, 1970; Nessov, 1981; Case and Schwimmer, 1988; Cicimurri, 2007). Fewer Mesozoic fossil elopomorphs have been described from Gondwanan deposits (Hector, 1874; da Silva Santos, 1971; Noubhani and Cappetta, 1994; Ostrowski, 2012; Cappetta et al., 2014; Halliday et al., 2016; Duque and Barreto, 2018).
The Upper Cretaceous strata of northwestern Madagascar, in the Mahajanga Basin (Figure 1), are known to contain very rich terrestrial vertebrate fossil assemblages (Krause et al., 2020). Over the past few decades, the Mahajanga Basin Project (MBP) has made many fossil discoveries and descriptions from this region. The MBP was initiated in 1993 by David W. Krause, then of Stony Brook University, and now of the Denver Museum of Nature \& Science, in collaboration with the University of Antananarivo in Antananarivo, Madagascar. The fossil fishes described here are a product of that project. These Upper Cretaceous deposits of the Mahajanga Basin contain elopomorpha vertebrae in addition to teeth and jaw elements belonging to three genera of elopomorphs.

\section{GEOLOGICAL SETTING}

The geology and landscape of the Mahajanga Basin in northwestern Madagascar is dominated by four sedimentary formations overlying widespread Coniacian (89.8 - 86.3 m.y.a.) flood basalts deposited around the time Madagascar became geographically isolated (Boast and Nairn, 1982; Storey et al., 1995). The most fossiliferous formation is the

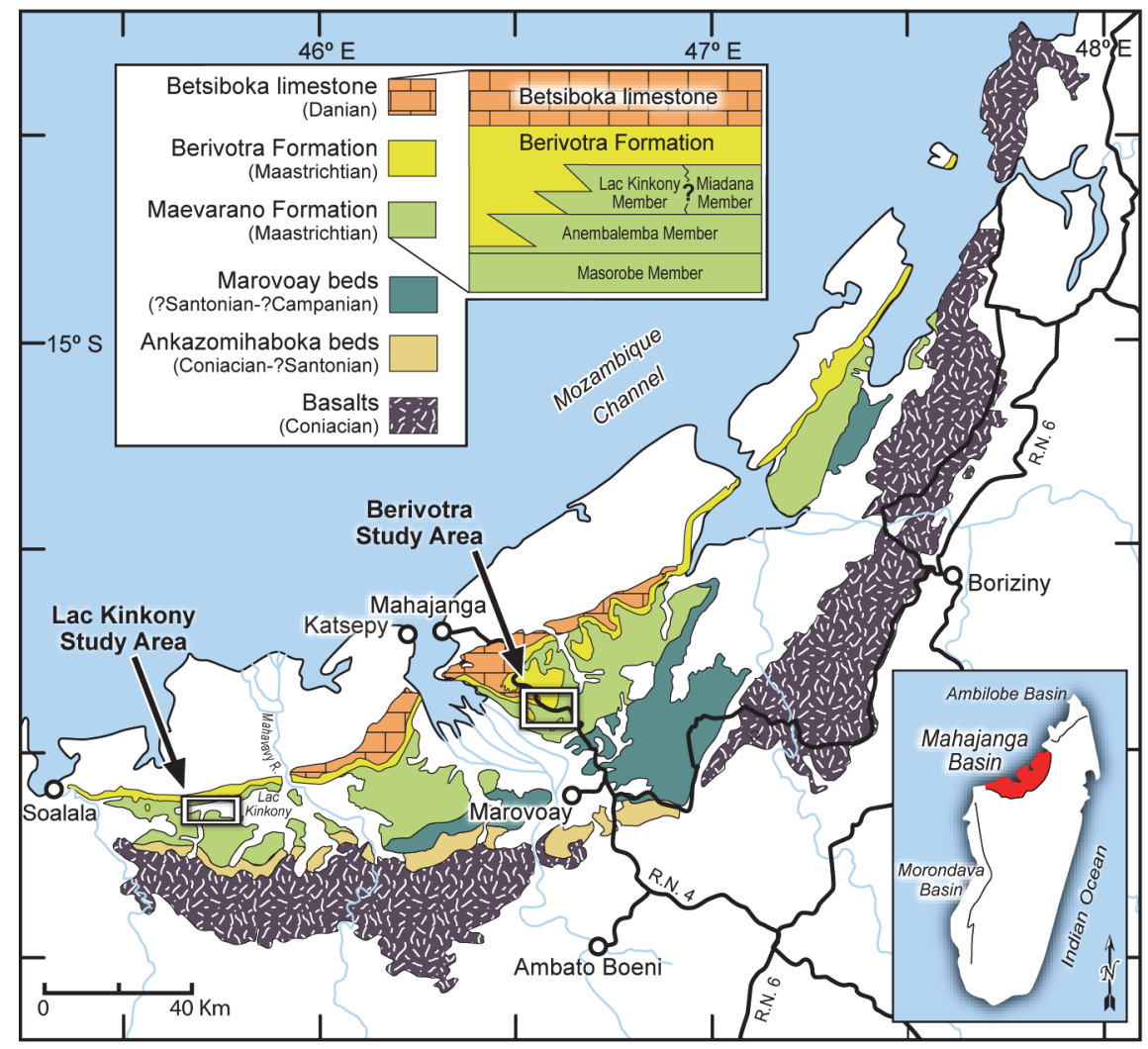

FIGURE 1. Geologic map of the Mahajanga Basin field area in northwestern Madagascar, including Berivotra and Lac Kinkony Study Areas. Modified with permission from Rogers et al. (2013). 
Maastrichtian Maevarano Formation (72.1-66.0 m.y.a.), which is primarily terrestrial or coastal and interfingers with the strictly marine Berivotra Formation (Rogers et al., 2000). The palaeoenvironmental setting of the Maevarano Formation is deduced to be a low-relief alluvial plain, with the crystalline highlands to the southeast, and the Mozambique Channel to the northwest (Rogers et al., 2000). The fossil bearing members of the Maevarano Formation consist of four depositional units exhibiting continental to nearshore-marine environments (Figure 1). Fragmentary fish material has been found in all four members of this formation (Rogers et al., 2013). The elopomorphs described here occur within three of these members, the Anembalemba Member, Lac Kinkony Member, and the Miadana Member.

The Anembalemba Member sequence consists of two interbedded facies and contains the most abundant and well-preserved fossils within the Maevarano Formation. Some notable finds include the dinosaurs Majungasaurus crenatissimus (Depéret, 1886; Krause et al., 2007) and Rapetosaurus krausei (Curry Rogers and Forster, 2001), the crocodiliform Simosuchus clarki (Buckley et al., 2000; Krause and Klay, 2010), the mammal Adalatherium hui (Krause et al., 2020), and the bird Falcatakely forsterae (O'Connor et al., 2020). Rogers et al. (2000) described the paleoenvironments as a product of downstream migration of fluvial bedforms (Facies 1) with rapid sediment dumping and debris flows (Facies 2). The Lac Kinkony Member exposures overlie the Anembalemba Member and contain abundant fish material along with crocodyliforms, turtles, the mammal Vintana sertichi (Krause et al., 2014), and nonavian dinosaurs (Rogers et al., 2013). Most vertebrate fossils in the Lac Kinkony Member are concentrated in microfossil bonebeds embedded within sandstones. This geology indicates a palaeoenvironment of siliciclastic and carbonate tidal flats dissected by tidally influenced rivers (Rogers et al., 2013). The Miadana Member is made of claystone, siltstone, and sandstone but exposures and fossils are rare and indicate a marine influenced environment (Rogers et al., 2000).

The localities of the fishes from this text are marked on Figure 1. The "Berivotra Study Area" is $\sim 35 \mathrm{~km}$ southeast of the city of Mahajanga and is named after the village of Berivotra, near which many of the vertebrate fossils have been found by the MBP. Berivotra has localities from the Anembalemba Member and the Miadana Member. The "Lac Kinkony Study Area" is located $\sim 65$ km south- west of the city of Katsepy and $\sim 40 \mathrm{~km}$ east of Soalala and named for the nearby lake, Lac Kinkony.

\section{MATERIAL AND METHODS}

The fossil fish material from the Upper Cretaceous of Madagascar was collected by the MBP by standard surface collection and screen-washing methods at microsite localities during the field seasons ranging from 1993-2007. Based on collaboration agreements between the University of Antananarivo and first Stony Brook University and subsequently the Denver Museum of Nature \& Science, the specimens were assigned catalog numbers based on the institution in which they will be permanently reposited. University of Antananarivo collections have a UA prefix while those housed at Denver Museum of Nature \& Science have a DMNH prefix. All images were captured with a digital camera.

\section{Institutional Abbreviations}

UA - University of Antananarivo, Antananarivo, Madagascar. DMNH EVP - Denver Museum of Nature \& Science, Denver, Colorado, United States of America. NHM - Natural History Museum, London, United Kingdom. FMNH - Field Museum of Natural History, Chicago, Illinois, United States of America. UMMZ - University of Michigan Museum of Zoology, Ann Arbor, Michigan, United States of America.

\section{SYSTEMATIC PALEONTOLOGY}

\author{
Class ACTINOPTERYGII Cope, 1887 \\ Superorder ELOPOMORPHA Greenwood et al., \\ 1966 \\ Order ALBULIFORMES Greenwood, 1977 \\ Family ALBULIDAE Bleeker, 1849 \\ Genus ALBULA Scopoli, 1777 \\ Albula sp. \\ Figure 2
}

Material. Tooth plate (UA 11388) and dentary (DMNH EPV. 136301).

Occurrence. Berivotra Study Area (Anembalemba Member).

Description. The oral tooth plate UA 11388 (Figure $2 A-B$ ) measures $6 \mathrm{~mm}$ along the longest axis and $4 \mathrm{~mm}$ wide. The base is made of thin bone with broken edges. On the occlusal side, there are 37 pedestaled teeth ranging in size from 0.5-1.0 $\mathrm{mm}$ in diameter across the crown and $1 \mathrm{~mm}$ in height. There are 10 alveolar pits, most filled with broken tooth bases. The opposite side of the bony base has a smooth texture with a small ridge of 


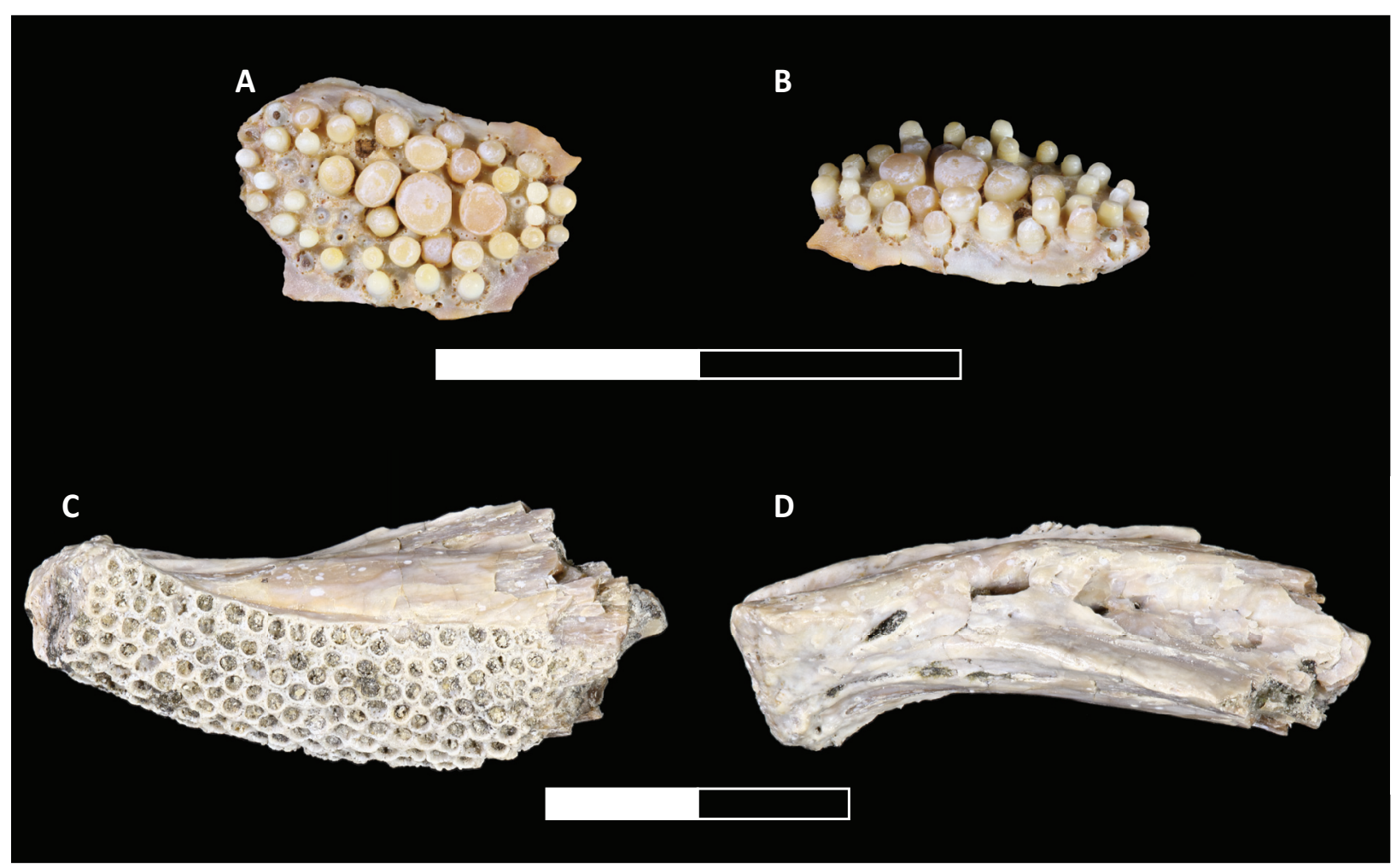

FIGURE 2. Albula sp. fossils from the Maevarano Formation. A-B, occlusal and lateral view of tooth plate (UA 11388). C-D, occlusal and ventral view of dentary (DMNH EPV. 136301). Scale bars equal $1 \mathrm{~cm}$.

bone, likely a muscle scar, less than $2 \mathrm{~mm}$ in height. This incomplete specimen does not have enough anatomical information to determine the exact placement of the bone within the oral cavity.

DMNH EPV. 136301 (Figure 2C-D) is a left dentary with a complete symphysial end, but incomplete, posterior articular end. The dentary measures $2.1 \mathrm{~cm}$ long, $0.5 \mathrm{~cm}$ wide, and $1.0 \mathrm{~cm}$ at its deepest point. Covering the dorsal surface, there is a rectangular tooth patch with 134 distinct, evenly spaced pits to accommodate villiform teeth. Each tooth pit measures $1 \mathrm{~mm}$ in diameter. The symphysial end is $0.7 \mathrm{~cm}$ deep and vertically oriented. The lateral side of the dentary has several large foramina. The ventral margin has a prominent keel with a deep groove and a series of foramina for a sensory canal.

Remarks. Albulids have tooth plates with a crushing dentition that are used in benthic environments for preying upon small invertebrates (Forey, 1973). Within Albula, there are hundreds of small, pedestal-shaped teeth within the oral cavity as depicted by Applegate (1970). The dentary of DMNH EPV. 136301 (Figure 2C-D) is directly comparable with similarly aged fossils of Albula dunklei (FMNH P27494) from the Selma Formation in Alabama
(Applegate, 1970) and recent Albula vulpes (UMMZ 186965-S) skeletons. Albula maxillae and dentaries have a large "tooth patch" to accommodate hundreds of villiform teeth (Applegate, 1970). The modern Albula dentary was described as having a near vertical symphysial margin, an extremely wide gutter on the ventral portion of the dentary (for the mandibular sensory canal) that opens laterally for most of its length (Nybelin, 1976) as seen in DMNH EPV. 136301.

\section{Class ACTINOPTERYGII Cope, 1887}

Superorder ELOPOMORPHA Greenwood et al., 1966

Order ELOPIFORMES Sauvage, 1875

Family PHYLLODONTIDAE Sauvage, 1875

Subfamily PHYLLODONTINAE Sauvage, 1875

Genus EGERTONIA Cocchi, 1864

Egertonia sp.

Figure 3

Material. Four tooth plates (UA 11389, DMNH EPV. 136302, DMNH EPV.136303, and UA 11390).

Occurrence. Berivotra Study Area (Anembalemba Member and Miadana Member).

Description. Tooth plate UA 11389 (Figure 3A-B) is incomplete on both ends and measures $0.9 \mathrm{~cm}$ 


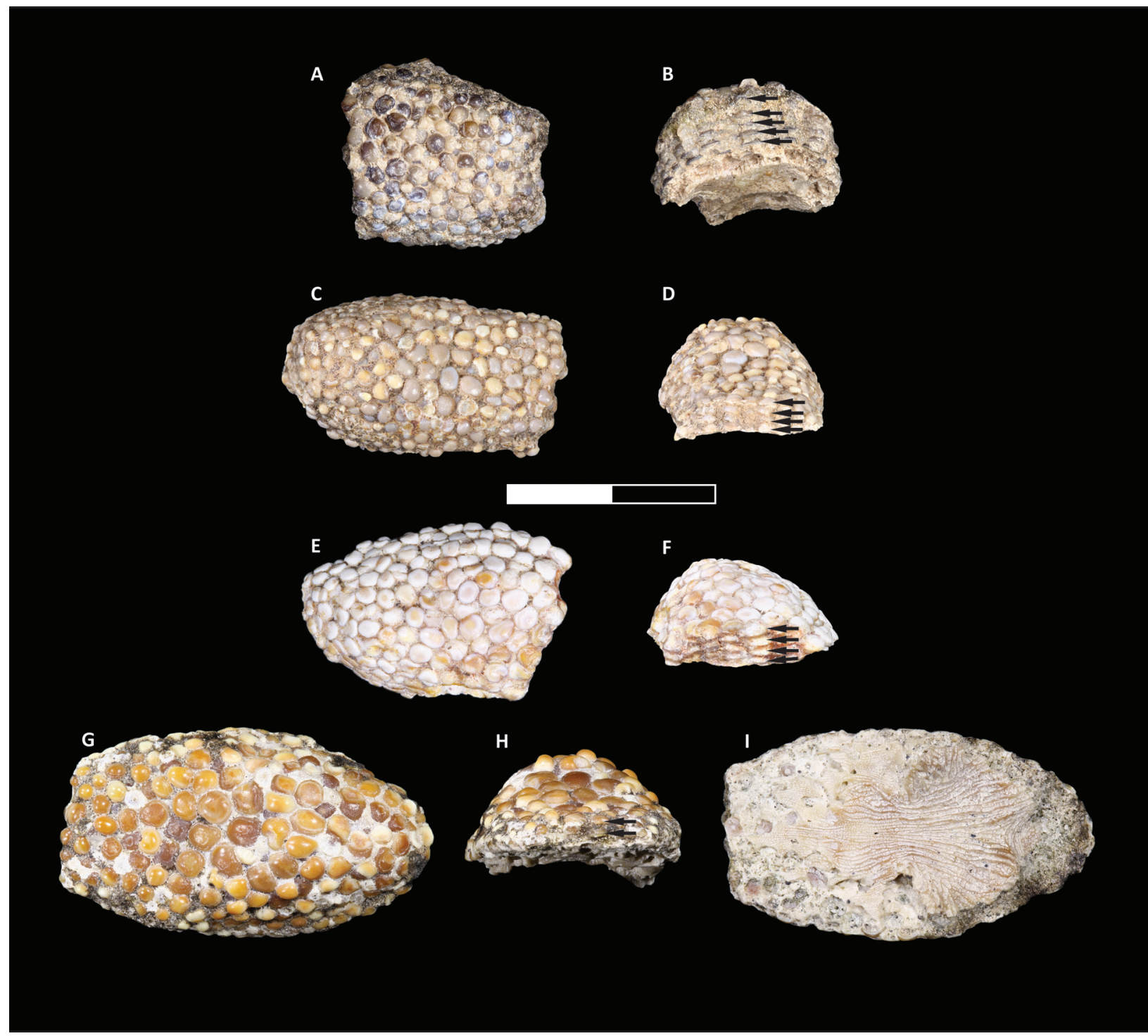

FIGURE 3. Egertonia sp. fossils from the Maevarano Formation. A-B, occlusal and cross-section views of tooth plate (UA 11389). C-D, occlusal and cross-section views of tooth plate (DMNH EPV. 136302). E-F, occlusal and cross-section views of tooth plate (DMNH EPV.136303). G-I, occlusal, cross-section, and basal views of tooth plate (UA 11390). Scale bar equals $1 \mathrm{~cm}$; small arrows used in cross-section view to highlight vertically stacked teeth.

long, and $0.9 \mathrm{~cm}$ wide; the height is domed and ranges from $0.2-0.4 \mathrm{~cm}$ in thickness. On cross-sectional view through the thicker portion, there are five layers of vertically stacked teeth. The teeth are flattened hemispheres and range in width from 0.25-1 $\mathrm{mm}$ at the crown and have a smooth or slightly punctate surface texture. There is a remnant of a bony base that exhibits symmetry, but it is incomplete with little surface texture. Tooth plate DMNH EPV.136302 (Figure 3C-D) measures 1.4 $\mathrm{cm}$ long, $0.8 \mathrm{~cm}$ wide, and ranges in thickness from $0.2-0.5 \mathrm{~cm}$. There is no clear bony base present, the surface is smooth, and the thin end is broken and incomplete. Upon view in cross-section through the tooth plate, there are four layers of vertically stacked teeth. Individual teeth are mostly complete and flattened hemispheres range in size from $0.25-1 \mathrm{~mm}$ in width at the crown and have a smooth or slightly punctate texture. Tooth plate DMNH EPV.136303 (Figure 3E-F) measures 1.25 $\mathrm{cm}$ long and $0.8 \mathrm{~cm}$ wide, and ranges in thickness from $0.2-0.6 \mathrm{~cm}$ tall. The thicker end is relatively complete, but the thin end is broken. In cross-section there are four layers of vertically stacked teeth. Individual teeth are flattened hemispheres and have a uniform size distribution of $1 \mathrm{~mm}$ across the crown with a relatively smooth surface texture. No bony base is present. Tooth plate UA 11390 (Fig- 
ure 3G-I) is oblong and $1.7 \mathrm{~cm}$ long, $0.9 \mathrm{~cm}$ wide, and ranges in thickness from $0.2-0.5 \mathrm{~cm}$ thick. The thicker end is complete, and the thin end is nearly complete, which shows vertically stacked teeth in cross-section. Individual teeth are flattened hemispheres and range from $0.25-1.0 \mathrm{~mm}$ in crown width and are mostly smooth in texture with relatively thick enamel. Opposite the occlusal surface, there is a poorly preserved, symmetrical, partial bony base with cortical bone texture.

Remarks. The first account of Egertonia from the Maevarano was mentioned by Gottfried and Krause (1999) and further described in the $\mathrm{PhD}$ thesis of Ostrowski (2012). Egertonia is an extinct genus within Phyllodontidae. Egertonia tooth plates are defined by having three characteristics: 1 ) vertically stacked replacement teeth; 2 ) regularly convex (nearly hemispherical or flattened) teeth; and 3) relatively thick enamel (Estes, 1969). These tooth plates alone cannot be identified finer than genus level. The holotype for Egertonia isodonta (NHM 38814) exhibits all three of these characteristics and is directly comparable to the four Madagascar specimens described above.

Class ACTINOPTERYGII Cope, 1887

Superorder ELOPOMORPHA Greenwood et al., 1966

Order ELOPIFORMES Sauvage, 1875

Family PHYLLODONTIDAE Sauvage, 1875

Subfamily PHYLLODONTINAE Sauvage, 1875

Genus PARALBULA Blake, 1940

Paralbula sp.

Figure 4

Material. Three tooth plates (DMNH EPV.136304, UA 11391, and UA 11392).

Occurrence. Berivotra Study Area (Anembalemba Member) and Lac Kinkony Study Area (Lac Kinkony Member).

Description. Tooth plate DMNH EPV.136304 (Figure $4 A-B$ ) measures $1.4 \mathrm{~cm}$ long, $0.8 \mathrm{~cm}$ wide, and ranges in thickness from $0.1-0.3 \mathrm{~cm}$. Lateral view of the tooth plate exhibits three to four layers of hemispherical teeth with irregular (offset, non-vertical) stacking. Individual teeth are $0.5-1.0 \mathrm{~mm}$ wide at the crown. No bony base is present. Tooth plate UA 11391 (Figure 4C-D) is incomplete with uneven margins and measures $1.1 \mathrm{~cm}$ long, $0.9 \mathrm{~cm}$ wide, and $0.25 \mathrm{~cm}$ thick. The thickness is relatively uniform with a slight undulating surface. The teeth are arranged in three or four layers with irregular stacking. Individual teeth are hemispherical with thick enamel exhibiting a punctate surface texture and are uniform at $1 \mathrm{~mm}$ in crown width. Tooth plate UA 11392 (Figure 4E-F) measures $1.2 \mathrm{~cm}$ long, $0.6 \mathrm{~cm}$ wide, and ranges in thickness from $0.2-0.4 \mathrm{~cm}$. The overall surface of the tooth plate is not smooth and shows undulations. From a lateral view of the tooth plate, the teeth are arranged in two to three layers with irregular stacking. Individual teeth range from 1-2 mm in width across the crown; many have broken enamel, and a punctate surface texture. Very little, poorly preserved bony base is present.

Remarks. Paralbula tooth plates are identified on the basis of the following criteria: 1) alternate tooth placement; 2) hemispherical teeth with a basilar foramen; 3) tooth surface is smooth or sparsely punctate (can occur radially); and 4) tooth plate with a curved occlusal surface (Estes, 1969). The tooth plates described here exhibit domed occlusal surfaces that are slightly flattened anatomically, not from deformation. Individual teeth have relatively smooth surface textures, and are hemispherical or slightly flattened, irregular to slightly elongate, with thick enamel. The individual teeth are strongly cemented together, and several of the teeth are weathered on the occlusal surfaces. These tooth plates identified as Paralbula occur mostly within the Lac Kinkony Member but have been found in the Anembalemba Member. The holotype specimen of Paralbula marylandica, from the Eocene of Maryland (Blake, 1940), possesses the four features listed above and is directly comparable to the Paralbula tooth plates from Madagascar.

Class ACTINOPTERYGII Cope, 1887

Superorder ELOPOMORPHA Greenwood et al., 1966

Genus indet. Figure 5

Material. Six vertebrae (DMNH EPV.136305, DMNH EPV.136306, DMNH EPV.136307, DMNH EPV.136308, UA 11393, UA 11394,)

Occurrence. Berivotra Study Area (Anembalemba Member) and Lac Kinkony Study Area (Lac Kinkony Member).

Description. The elopomorph vertebrae from Madagascar encompass a wide range of morphotypes (Figure 5) and are found across several localities within the Maevarano Formation. These amphicoelous vertebrae range in size from small to large (less than $0.5 \mathrm{~cm}$ to over $2.5 \mathrm{~cm}$ at their widest point) and qualitative morphology from simple, slightly sub-circular, and thin (Figure $5 \mathrm{~A}, 5 \mathrm{C}-\mathrm{F}$ ) to robust with a highly sigmoidal margin (Figure $5 \mathrm{~B}$ ). These vertebrae are also rostro-caudally flattened (plate-like), exhibit fine parallel fibers around the perimeter from edge to edge (oriented rostro-caudally), and deeper articular pits that accommodate the neural arch (dorsal) are widely spaced from the 


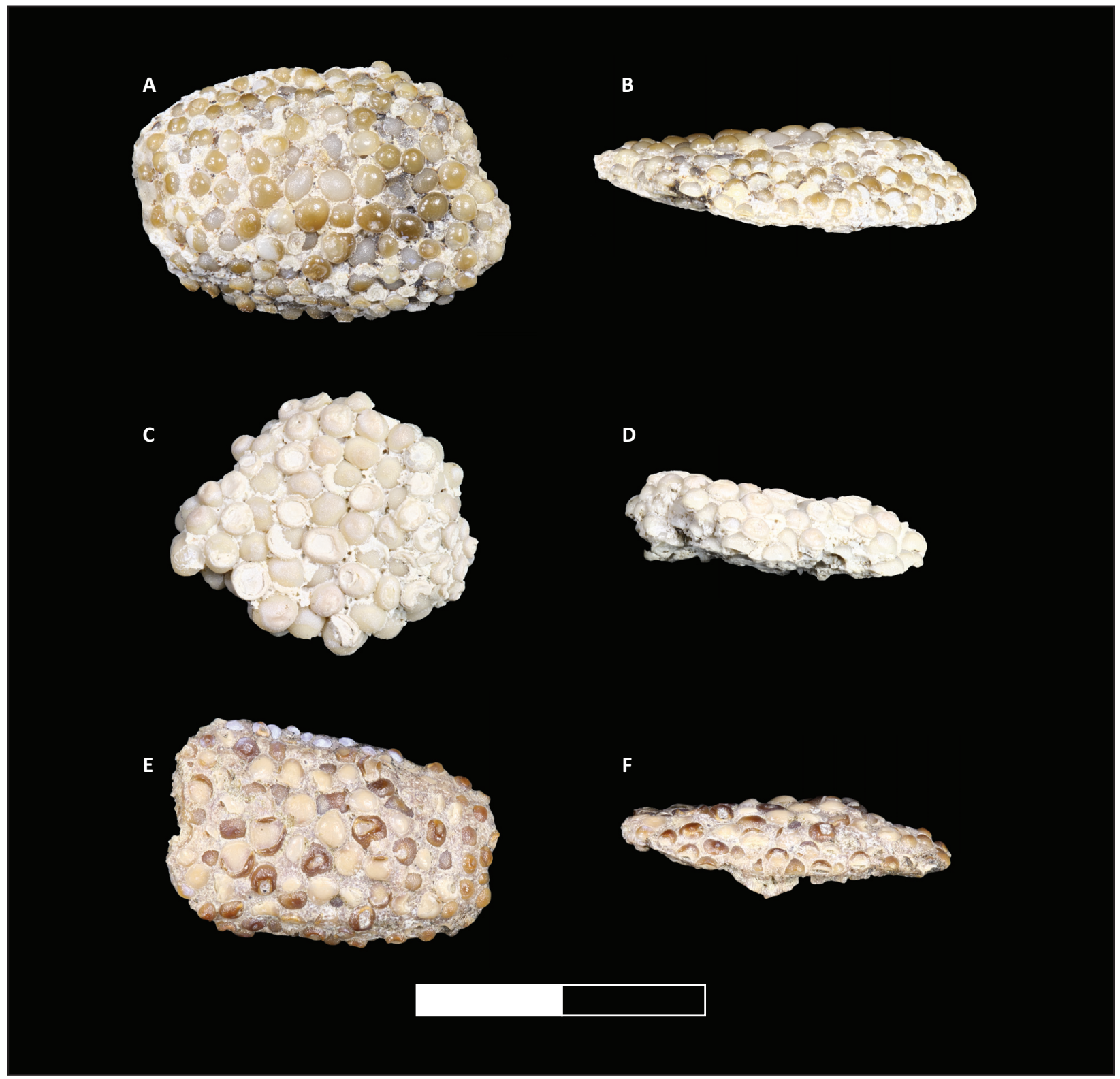

FIGURE 4. Paralbula sp. fossils from the Maevarano Formation. A-B occlusal and lateral views of tooth plate (DMNH EPV.136304). C-D occlusal and lateral views of tooth plate (UA 11391). E-F, occlusal and lateral views of tooth plate (UA 11392). Scale bar equals $1 \mathrm{~cm}$.

parapophyseal articular pits. Brinkman and Neuman (2002) noted that this combination of vertebral features are not found outside of Elopomorpha. The ventral side of the vertebrae may bear a shallow indentation to accommodate vasculature. Most of the elopomorph vertebrae from the Maevarano Formation are $1.0-1.5 \mathrm{~cm}$ at their widest point, and are subcircular. The vertebrae themselves are isolated, surface collected elements and not associated with any tooth plates. Because of the variability in teleost vertebrae within a single individual, we cannot assume a more specific taxonomic iden- tification of these isolated vertebrae. The majority of the large, robust vertebrae occur within the Lac Kinkony Member, which is also more likely to have Paralbula tooth plates, but no official association can be made. No detailed descriptions have noted differences in isolated vertebrae between Paralbula, Egertonia, and Albula.

\section{DISCUSSION}

Vertebrate preservation within the Maevarano Formation is inconsistent. More robust taxa (dino- 


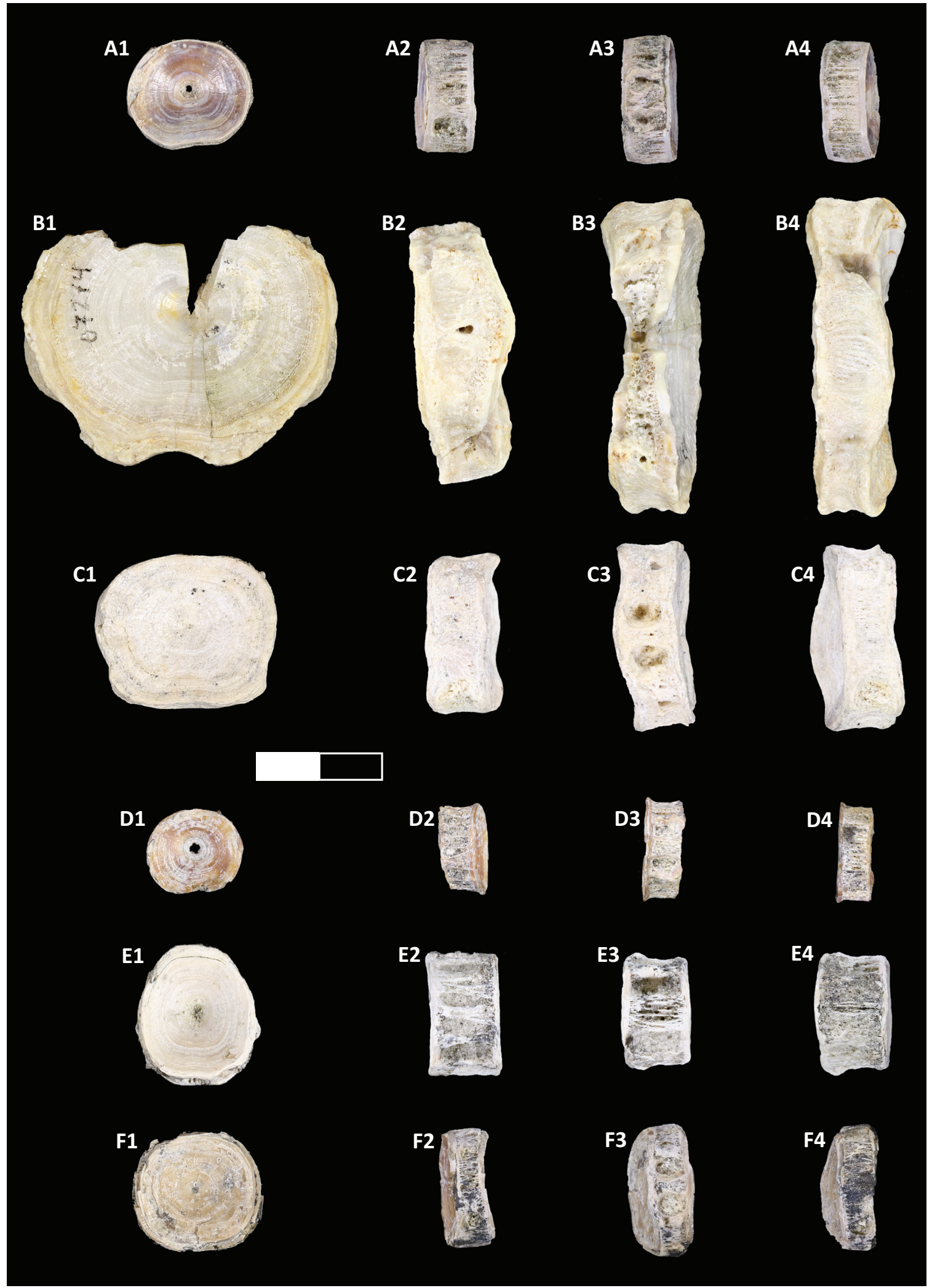

FIGURE 5. Elopomorpha gen. indet centra from the Maevarano Formation. Each specimen is shown in cranial view (1s), lateral view (2s), dorsal view (3s), and ventral view (4s). A, vertebra (DMNH EPV. 136305). B, vertebra (DMNH EPV. 136306), note that B3 shows a broken dorsal margin view. C, vertebra (DMNH EPV.136307). D, vertebra (DMNH EPV. 136308). E, vertebra (UA 11393). F, vertebra (UA 11394). Scale bar equals $1 \mathrm{~cm}$. 
saurs, crocodilians, etc.) are frequently found articulated and stunningly preserved (Rogers, 2005). Often, fossilized fish elements in the Maevarano Formation are disarticulated, disassociated, and broken. It is likely that these coastal marine fishes washed ashore during high-energy coastal events, which are part of Madagascar's natural history (Rogers et al., 1997). This preservation limits precise taxonomic identification for many of the fish fossils. However, some specimens are distinct enough to identify to the genus level. The Albula, Egertonia, and Paralbula fossil elements are diagnostic, especially the robust tooth plates and vertebrae, which have a greater likelihood of preservation. The description of three genera and their presence on Madagascar allows us to understand more about the distribution and diversity of these fishes during the Late Cretaceous. The presence of these genera in the Southern Hemisphere during the Late Cretaceous establish that these fishes had a broader (global) distribution than previously known based on their fossil records.

\section{Paleobiogeography}

Each of these elopomorph genera from Madagascar affects our understanding of their distributions during the Late Cretaceous (Figure 6).

Albula. The family Albulidae reached its peak diversity and abundance 100 million years ago, during the mid-Cretaceous (Colborn et al., 2001). Recent Albula are found in equatorial and subtropical, coastal waters worldwide. This occurrence of Albula in Madagascar during the Late Cretaceous is the first record of Albula in the Southern Hemisphere at that time. The majority of Albula fossils from the Cretaceous are in North America (Hay, 1907; Wade, 1926; Russell and Landes, 1937; Stephenson, 1941; Bergquist, 1944; Zangerl, 1948; Reeside, 1955; Miller, 1967; Applegate, 1970; Sohl and Koch, 1983; Schwimmer, 1986; Case and Schwimmer, 1988; Grandstaff et al., 1992; Cicimurri, 2007), along with a few specimens from Uzbekistan (Nessov, 1981; Nessov, 1985). The occurrence of Albula in Madagascar greatly extends the geographical range of this genus into the Southern Hemisphere during the Late Cretaceous (Figure 6).

Egertonia. The presence of Egertonia in the Late Cretaceous extends the known temporal range of this genus into the Maastrichtian (Ostrowski, 2012). The Madagascar specimens, along with a description of Egertonia from the Late Cretaceous of southern India (Halliday et al., 2016), places the two earliest (and only known Cretaceous) records of Egertonia in the Southern Hemisphere (Figure 6).

Paralbula. Paralbula is known from the Cretaceous in the Northern Hemisphere, mostly from North America (Hay, 1907; Estes, 1965; Langston, Jr., 1967; Miller, 1967; Estes, 1969; Sahni, 1972; Langston, Jr., 1975; Armstrong-Ziegler, 1978; Dodson, 1984; Lauginiger, 1984; Hutchinson and Kues, 1985; Brinkman, 1986; Danis, 1986; Schwimmer, 1986; Case, 1987; Case and Schwimmer, 1988; Fiorillo, 1989; Brinkman, 1990; Grandstaff et al., 1992; Storer, 1993; Eberth and Brinkman, 1997; Beavan and Russell, 1999; Lillegraven and Eberle, 1999; Gardner, 2000; Peng et al., 2001; Cicimurri, 2007; Brinkman, 2008; Montgomery and Clark, 2016; Hoganson et al., 2019), and localities in Europe (Vullo et al., 2009). Given the regular occurrences of Paralbula from the Early Campanian to the Middle-Eocene, it is not surprising to have additional geographic occurrences of Paralbula within this timeframe. The presence of Paralbula in Madagascar extends the geographical distribution of this genus into the Southern Hemisphere during the Late Cretaceous (Figure 6).

As described above, the majority of these elopomorph genera have been found in the Northern Hemisphere, specifically North America and Europe. This is not surprising, as there is a sampling bias favoring Laurasian landmass exploration and taxonomic description (Benson et al., 2013) leading to an underrepresentation of Gondwanan taxa in the literature. As more expeditions and discoveries in Gondwanan landmasses are published, a more comprehensive picture is forming of spatial and temporal distributions of many taxa. The diversity of fossil elopomorphs and abundance of material in the Mahajanga Basin indicates that these taxa were a major component of the aquatic fauna in these coastal ecosystems during the Late Cretaceous. The taxa described here are most similar to what is present in the Northern Hemisphere and especially comparable to numerous North American localities biogeographically (Ostrowski, 2012). The presence of these elopomorphs in Madagascar, therefore, supports a more widespread distribution, spatially and temporally, of these genera than previously thought.

\section{Evolution within Elopomorpha}

These three elopomorph genera nest within two different families in Elopomorpha; Albula within Albulidae, and Egertonia and Paralbula within Phyllodontidae. Currently, there exists an inherent collection bias in the known vertebrate fossil mate- 


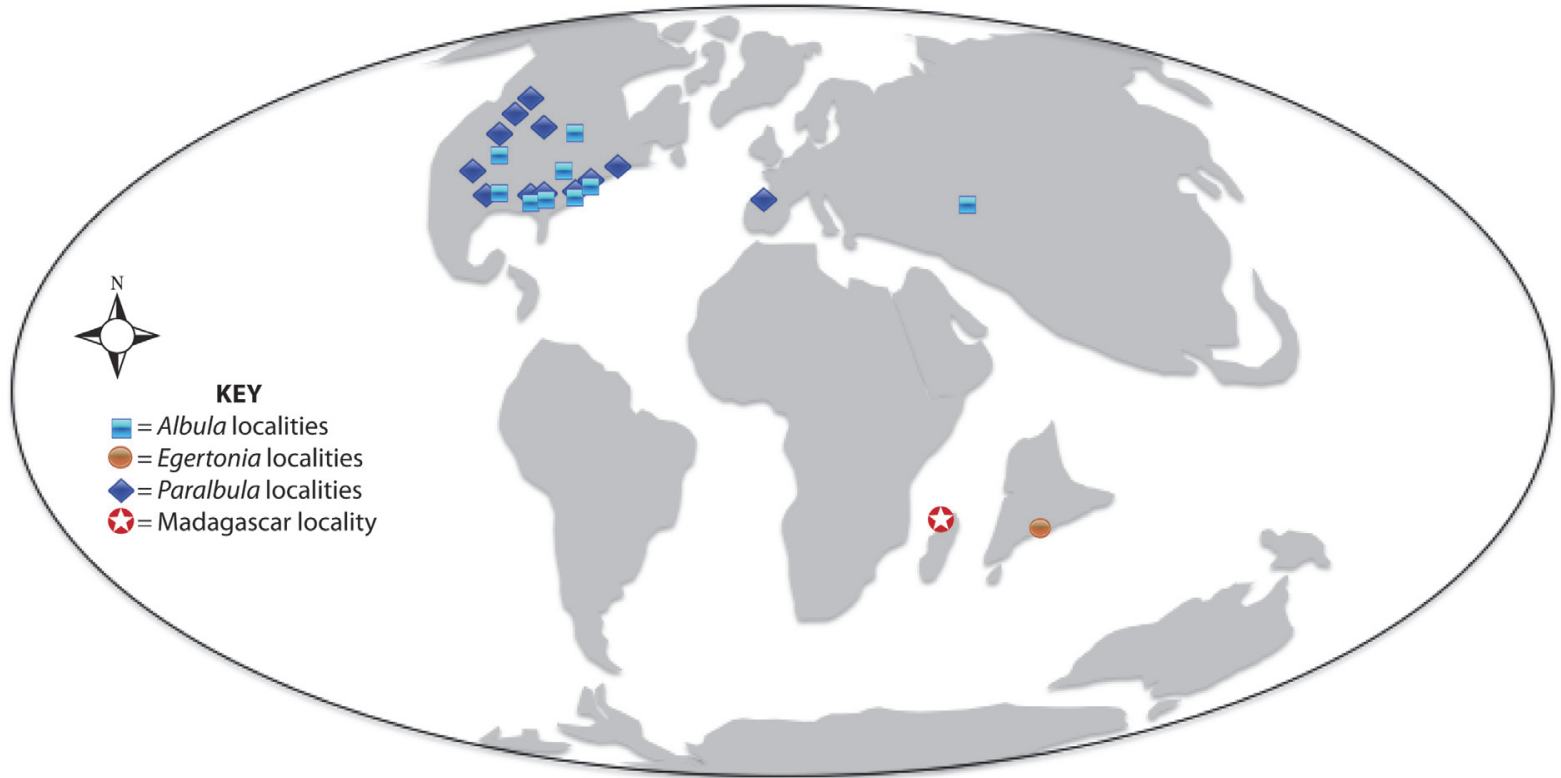

FIGURE 6. Late Cretaceous Paleogeographic Map showing known fossil localities (clustered by state if applicable) of Albula, Egertonia, and Paralbula and the location of the Madagascar fauna. PaleoMap modified from global Molleweide projection at $66 \mathrm{Ma}$ (Scotese, 2014). Localities are condensed by state or province in North America for clarity.

rial, namely a greater representation of "Laurasian taxa" over "Gondwanan taxa" (Benson et al., 2013). A compounding factor is that fishes can be difficult to identify to more specific taxonomic levels when they are disarticulated and disassociated. Some of the strongest hypotheses about the origin of certain elopomorph families and genera currently rest on Estes's evaluations, which stated the origin of phyllodontids occurred in the Cretaceous of North America (Estes, 1969) and later elaborated to specify shallow epicontinental seas in the North Atlantic and around North America (Estes and Hiatt, 1978). This hypothesis is predicated by the "Laurasian pull" of described taxa. With the presence of a diverse assemblage of these genera in the Late Cretaceous of Madagascar, it is possible to hypothesize the origin and subsequent distribution of phyllodontids is more complex. The only known specimens of Egertonia in the Cretaceous are from Gondwanan landmasses of Madagascar (Gottfried and Krause, 1998; Ostrowski, 2012) and South India (Halliday et al., 2016). As in agreement with Halliday et al. (2016), these occurrences likely mean the origin of this genus is more complex than the purported Cretaceous North American (Estes, 1969) or North Atlantic (Estes and Hiatt, 1978) hypotheses.

\section{CONCLUSIONS}

The specimens described here represent three elopomorph genera: Albula, Egertonia, and Paralbula, present in Madagascar during the Late Cretaceous. The presence of these fishes within this coastal environment supports the deltaic and coastal marine-influenced paleoenvironment based on geologic data (Rogers et al., 2000; Rogers, 2005; Rogers et al., 2013). The presence of these fishes on a Gondwanan landmass also supports the idea of a broader distribution of these elopomorphs during the Late Cretaceous, which was previously limited to the Northern Hemisphere. The likeness of specimens further supports a faunal similarity between the Indian subcontinent and Madagascar even 20 million years after the separation of these landmasses. The Albula and Paralbula described here represent the only southern hemisphere occurrences in the Late Cretaceous and in the case of Egertonia, also the oldest. This improves our understanding of the distribution and biogeography in these elopomorphs during the Late Cretaceous, signifying a more global distribution than previously documented. Multiple early occurrences of Egertonia present in the Southern Hemisphere indicates a more complex origin of some elopomorph groups. These fossils also contribute to our understanding of diversity in coastal 
marine ecosystems within Madagascar and Gondwana as a whole during the Late Cretaceous.

\section{ACKNOWLEDGEMENTS}

The author wishes to thank M. Gottfried and D. Krause for assistance and discussion on the project, A. Lownsdale and the Denver Museum of
Nature \& Science who provided photographs of specimens, and R. Rogers for permission to use Figure 1. Funding for this project was provided through grants from the National Science Foundation to D. Krause. This manuscript was improved thanks for comments from four anonymous reviewers and handling editor $O$. Kovalchuk.

\section{REFERENCES}

Applegate, S.P. 1970. The vertebrate fauna of the Selma Formation of Alabama. Fieldiana, Geology Memoirs, 3:383-433. https://doi.org/10.5962/bhl.title.5224

Armstrong-Ziegler, J.G. 1978. An aniliid snake and associated vertebrates from the Campanian of New Mexico. Journal of Paleontology, 52:480-483. http://www.jstor.org/stable/1303718

Arratia, G. 1997. Basal teleosts and teleostean phylogeny. Palaeo Ichthyologica, 7:5-168.

Arratia, G. 2000. Remarkable teleostean fishes from the Late Jurassic of southern Germany and their phylogenetic relationships. Fossil Record, 3:137-179. https://doi.org/10.1002/mmng.20000030108

Beavan, N.R. and Russell, A.P. 1999. An elasmobranch assemblage from the Terrestrial-Marine Transitional Lethbridge Coal Zone (Dinosaur Park Formation: Upper Campanian), Alberta, Canada. Journal of Paleontology, 73:494-503. https://doi.org/10.1017/s0022336000028006

Benson, R.B.J., Mannion, P.D., Butler, R.J., Upchurch, P., Goswami, A., and Evans, S.E. 2013. Cretaceous tetrapod fossil record sampling and faunal turnover: Implications for biogeography and the rise of modern clades. Palaeogeography, Palaeoclimatology, Palaeoecology, 372:88-107. https://doi.org/10.1016/j.palaeo.2012.10.028

Bergquist, H.R. 1944. Cretaceous of the Mesabi Iron Range, Minnesota. Journal of Paleontology, 18:1-30. http://www.jstor.org/stable/1299188

Betancur-R.R., Wiley, E.O., Arratia, G., Acero, A., Bailly, N., Miya, M., Lecointre, G., and Ortí, G. 2017. Phylogenetic classification of bony fishes. BMC Evolutionary Biology, 17:162. https://doi.org/10.1186/s12862-017-0958-3

Blake, S. 1940. Paralbula, a new fossil fish based on dental plates from the Eocene and Miocene of Maryland. Journal of the Washington Academy of Sciences, 30:205-209.

Bleeker, P. 1849. Bijdrage tot de kennis der ichthyologische fauna van het eiland Madura, met beschrijving van eenige nieuwe soorten. Verhandelingen van het Bataviaasch Genootschap van Kunsten en Wetenschappen, 22(8):1-16.

Boast, J. and Nairn, A.E.M. 1982. An outline of the geology of Madagascar, p. 649-696. In Nairn, A.E.M. and Stehli, F.G. (eds.), The Ocean Basins and Margins. Plenum, New York. https://doi.org/10.1007/978-1-4615-8038-6_14

Brinkman, D. 1986. Microvertebrate sites: progress and prospectus. In Naylor, B.G. (ed.), Field Trip Guidebook to Dinosaur Provincial Park, 2 June 1986. Dinosaur Systematics Symposium. p. 24-37. Tyrrell Museum of Paleontology, Drumheller, Alberta.

Brinkman, D. 1990. Paleooecology of the Judith River Formation (Campanian) of Dinosaur Provincial Park, Alberta, Canada: evidence from vertebrate microfossil localities. Palaeogeography, Palaeoclimatology, Palaeoecology, 78:37-54. https://doi.org/10.1016/0031-0182(90)90203-j

Brinkman, D. 2008. The structure of the Late Cretaceous (late Campanian) non-marine aquatic communities: a guild analysis of two vertebrate microfossil localities in Dinosaur Provincial Park, Alberta, Canada, p. 33-59. In Sankey, J.T. and Baszio, S. (eds.), Vertebrate Microfossil Assemblages: their Role in Paleoecology and Paleobiogeography. Indiana University Press, Bloomington, Indiana.

Brinkman, D. and Neuman, A. 2002. Teleost centra from the Uppermost Judith River Group (Dinosaur Park Formation, Campanian) of Alberta, Canada. Journal of Paleontology, 76 (1):138-155. https://doi.org/10.1017/S002233600001742X

Buckley, G.A., Brochu, C.A., Krause, D.W., and Pol, D. 2000. A pug-nosed crocodyliform from the Late Cretaceous of Madagascar. Nature, 405:941-944. https://doi.org/10.1038/35016061 
Cappetta, H., Bardet, N., Suberbiola, X.P., Adnet, S., Akkrim, D., Amalik, M., and Benabdallah, A. 2014. Marine vertebrate faunas from the Maastrichtian phosphates of Benguérir (Ganntour Basin, Morocco): Biostratigraphy, palaeobiogeography and palaeoecology. Palaeogeography, Palaeoclimatology, Palaeoecology, 409:217-238. https://doi.org/10.1016/j.palaeo.2014.04.020

Case, G.R. 1987. Borodinopristis schwimmeri, a new ganopristine sawfish from the Upper Blufftown Formation (Campanian) of the Upper Cretaceous of Georgia. Bulletin New Jersey Academy of Science, 32(1):25-32.

Case, G.R. and Schwimmer, D.R. 1988. Late Cretaceous fish from the Blufftown Formation (Campanian) in Western Georgia. Journal of Paleontology, 62:290-301. https://doi.org/10.1017/s0022336000029942

Chen, J.-N., López, J.A., Lavoué, S., Miya, M., and Chen, W.-J. 2014. Phylogeny of the Elopomorpha (Teleostei): Evidence from six nuclear and mitochondrial markers. Molecular Phylogenetics and Evolution, 70:152-161. https://doi.org/10.1016/j.ympev.2013.09.002

Cicimurri, D.J. 2007. A late Campanian (Cretaceous) selachian assemblage from a classic locality in Florence County, South Carolina. Southeastern Geology, 45(2):59-72.

Cocchi, I. 1864. Monografia dei Pharyngodopilidae, nuova famiglia di pesci labroidi. Annali del Museo di fisica e storia natuale di Firenze, 1:65-152. https://doi.org/10.5962/bhl.title.61006

Colborn, J., Crabtree, R.E., Shaklee, J.B., Pheiler, E., and Bowen, B.W. 2001. The evolutionary enigma of bonefishes (Albula spp.): Cryptic species and ancient separations in a globally distributed shorefish. Evolution, 55:807-820. https://doi.org/10.1111/j.0014-3820.2001.tb00816.x

Cope, E.D. 1887. Zittel's Manual of Palaeontology. American Naturalist, 21:1014-1019.

Curry Rogers, K. and Forster, C.A. 2001. The last of the dinosaur titans: A new sauropod from Madagascar. Nature, 412:530-534. https://doi.org/10.1038/35087566

Danis, J. 1986. Quarries of Dinosaur Provincial Park, p. 43-51. In Naylor, B.G. (ed.), Field Trip Guidebook to Dinosaur Provincial Park, 2 June 1986. Dinosaur Systematics Symposium. Tyrrell Museum of Paleontology, Drumheller, Alberta.

Dartevelle, E. and Casier, E. 1943. Les poissons fossiles du Bas-Congo et de régions voisines (Premiére Partie). Annales du Musée du Congo belge, Serial A, 2:1-200.

Da Silva Santos, R. 1971. Nouveau genre et espèce d'Elopidae du Bassin Sédimentaire de la Chapada do Araripe. Anais da Academia Brasileira de Ciências, 43:439-442.

Depéret, C. 1886. Note sur les Dinosauiens Sauropodes et Théropodes du Crétacé supérieur de Madagascar. Bulletin de la Société Géologique de France, 21:176-194.

Dodson, P. 1984. Small Judithian ceratopsids, Montana and Alberta, p. 73-78. In Reif, W.E. and Westphal, F. (eds.), Third Symposium on Mesozoic Terrestrial Ecosystems, Short Papers. Attempo Verlag, Tübingen.

Dornburg, A., Friedman, M., and Near, T.J. 2015. Phylogenetic analysis of molecular and morphological data highlights uncertainty in the relationships of fossil and living species of Elopomorpha (Actinopterygii: Teleostei). Molecular Phylogenetics and Evolution, 89:205-218. https://doi.org/10.1016/j.ympev.2015.04.004

Duque, R.R.C. and Barreto, A.M.F. 2018. New fossiliferous sites of the Romualdo Formation, Lower Cretaceous, Araripe Basin, Exu, Pernambuco, Northeast of Brazil. Anuário do Instituto de Geociências - UFRJ, 41(1):5-14. https://doi.org/10.11137/2018_1_05_14

Eberth, D. and Brinkman, D. 1997. Paleoecology of an estuarine, incised-valley fill in the Dinosaur Park Formation (Judith River Group, Upper Cretaceous) of Southern Alberta, Canada. Palaios, 12(1):43-58. https://doi.org/10.2307/3515293

Estes, R. 1965. A new fossil salamander from Montana and Wyoming. Copeia, 1965(1):90-95. https://doi.org/10.2307/1441245

Estes, R. 1969. Studies on fossil phyllodont fishes: interrelationships and evolution in the Phyllodontidae (Albuloidei). Copeia, 1969(2):317-331. https://doi.org/10.2307/1442082

Estes, R. and Hiatt, R. 1978. Studies on fossil phyllodont fishes: a new species of Phyllodus (Elopiformes: Albuloidea) from the Late Cretaceous of Montana, USA. Paleobios, 28:1-10.

Faircloth, B.C., Sorenson, L., Santini, F., and Alfaro, M.E. 2013. A phylogenomic perspective on the radiation of ray-finned fishes based upon targeted sequencing of ultraconserved elements (UCEs). PLoS ONE, 8(6):e65923. https://doi.org/10.1371/journal.pone.0065923

Fiorillo, A. 1989. The vertebrate fauna from the Judith River Formation (Late Cretaceous) of Wheatland and Golden Valley Counties, Montana. The Mosasaur, 4:127-142. 
Forey, P.L. 1973. A revision of the elopiform fishes, fossil and recent. Bulletin of the British Museum (Natural History) Geology - Supplement 10, London, England.

Gardner, J.D. 2000. Albanerpetonitid amphibians from the Upper Cretaceous (Campanian and Maastrichtian) of North America. Geodiversitas, 22(3):349-388.

Gottfried, M.D. and Krause, D.W. 1998. First record of gars (Lepisosteidae, Actinopterygii) on Madagascar: Late Cretaceous remains form the Mahajanga Basin. Journal of Vertebrate Paleontology, 18:275-279. https://doi.org/10.1080/02724634.1998.10011056

Grandstaff, B.S., Parris, D.C., Denton, Jr., R.K., and Gallagher, W.B. 1992. Alphadon (Marsupialia) and Multituberculata (Allotheria) in the Cretaceous of Eastern North America. Journal of Vertebrate Paleontology, 12:217-222. https://doi.org/10.1080/02724634.1992.10011450

Greenwood, P.H. 1977. Notes on the anatomy and classification of elopomorph fishes. Bulletin of the British Museum (Natural History), 131:65-102.

Greenwood, P.H., Rosen, D.E., Weitzman, S.H., and Meyers, G.S. 1966. Phyletic studies of teleostean fishes, with a provisional classification of living forms. Bulletin of the American Museum of Natural History, 131:339-456.

Halliday, T.J., Cuff, A.R., Prasad, G.V., Thanglemmoi, M.S., and Goswami, A. 2016. New record of Egertonia (Elopiformes, Phyllodontidae) from the Late Cretaceous of South India. Papers in Palaeontology, 2:284-294. https://doi.org/10.1002/spp2.1040

Hay, O.P. 1907. The Fossil Turtles of North America. Carnegie Institution of Washington Publication, Washington, D.C. USA, 75. https://doi.org/10.5962/bhl.title.21745

Hector, J. 1874. On the fossil Reptilia of New Zealand. Transactions and Proceedings of the Royal Society of New Zealand, 6:333-358.

Hoganson, J.W., Erickson, J.M., and Holland, Jr., F. 2019. Chondrichthyan and osteichthyan paleofaunas from the Cretaceous (Late Maastrichtian) Fox Hills Formation of North Dakota, USA: paleoecology, paleogeography, and extinction. Bulletins of American Paleontology, 398:1-94.

Hutchinson, P.J., and Kues, B.S. 1985. Depositional environments and paleontology of Lewis Shale to lower Kirtland shale sequence (Upper Cretaceous), Bisti area, northwestern New Mexico, New Mexico. Bureau of Mines and Mineral Resources Circular, 195:25-54.

Krause, D.W. and Klay, N.J. 2010. Simosuchus clarki (Crocodyliformes: Notosuchia) from the Late Cretaceous of Madagascar. Journal of Vertebrate Paleontology, $236 \mathrm{p.}$.

Krause, D.W., Sampson, S.D., Carrano, M.T., and O'Connor, P.M. 2007. Overview of the discovery, taxonomy, phylogeny, and biogeography of Majungasaurus crenatissimus (Theropoda: Abelisauridae) from the Late Cretaceous of Madagascar. Journal of Vertebrate Paleontology, 27(2, supplement):1-20. https://doi.org/10.1671/0272-4634(2007)27[1:OOTHOD]2.0.CO;2

Krause, D.W., Hoffmann, S., Wible, J.R., Kirk, E.C., Schultz, J.A., von Koenigswald, W., Groenke, J.R., Rossie, J.B., O'Connor, P.M., Seiffert, E.R., Dumont, E.R., Holloway, W.L., Rogers, R.R., Rahantarisoa, L.J., Kemp, A.D., and Andriamialison, H. 2014. First cranial remains of a gondwanatherian mammal reveal remarkable mosaicism. Nature, 515:512-517. https://doi.org/10.1038/nature13922

Krause, D.W., Hoffmann, S., Hu, Y., Wible, J.R., Rougier, G.W., Kirk, E.C., Groenke, J.R., Rogers, R.R., Rossie, J.B., Schultz, J.A., Evans, A.R., von Koenigswald, W., and Rahantarisoa, L.J. 2020. Skeleton of a Cretaceous mammal from Madagascar reflects longterm insularity. Nature, 581:421-427. https://doi.org/10.1038/s41586-020-2234-8

Langston, Jr., W. 1967. The thick-headed ceratopsian dinosaur Pachyrhinosaurus (Reptilia: Ornithischia), from the Edmonton Formation near Drumheller, Canada Canadian Journal of Earth Sciences, 4:171-186. https://doi.org/10.1139/e67-008

Langston, Jr., W. 1975. The ceratopsian dinosaurs and associated lower vertebrates from the St. Mary River Formation (Maestrichtian) at Scabby Butte, Southern Alberta. Canadian Journal of Earth Sciences, 12:1576-1608. https://doi.org/10.1139/e75-142

Lauginiger, E.M. 1984. An upper Campanian vertebrate fauna from the Chesapeake and Delaware Canal. The Mosasaur, 2:141-149.

Lillegraven, J.A., and Eberle, J.J. 1999. Vertebrate faunal changes through Lancian and Puercan time in southern Wyoming. Journal of Paleontology, 73:691-710. https://doi.org/10.1017/s0022336000032510

Miller, H.W. 1967. Cretaceous vertebrates from Phoebus Landing, North Carolina. Proceedings of the National Academy of Sciences of Philadelphia, 119:219-239. 
Montgomery, H. and Clark, S. 2016. Paleoecology of the Gaddis Site in the Upper Cretaceous Aguja Formation, Terlingua, Texas. Palaios, 31(7):347-357. https://doi.org/10.2110/palo.2015.099

Nessov, L. 1981. Nakhodka cheliusti naezemnoi lashcheritsy v verkhnem melu Uzbekistana (The discovery of a terrestrial lizard jaw in the Upper Cretaceous of Uzbekistan). Vestnik Leningradskogo Universiteta, 2:105-107.

Nessov, L. 1985. Rare bony fishes, terrestrial lizards and mammals in the estuarine and coastal lowland zone of the Kyzyl-Kum Cretaceous. Yearbook of the All-Union Paleontological Association, 28:199-219.

Noubhani, A. and Cappetta, H. 1994. Révision des Rhombodontidae (Neoselachii, Batomorphi) des bassins à phosphate du Maroc. Palaeovertebrata, 23:1-49.

Nybelin, O. 1976. Note on the osteology of the lower jaw of Albula vulpes (L.) (Pisces, Teleostei). Zoologica Scripta, 5:235-237. https://doi.org/10.1111/j.1463-6409.1976.tb00704.x

O'Connor, P.M., Turner, A.H., Groenke, J.R., Felice, R.N., Rogers, R.R., Krause, D.W., and Rahantarisoa, L.J. 2020. Late Cretaceous bird from Madagascar reveals unique development of beaks. Nature, 588:272-276. https://doi.org/10.1038/s41586-020-2945-x

Ostrowski, S.A. 2012. The teleost ichthyofauna from the Late Cretaceous of Madagascar: systematics, distribution, and implications for Gondwanan biogeography. PhD thesis, Michigan State University, East Lansing, MI, USA.

Peng, J., Russell, A.P., and Brinkman, D.B. 2001. Vertebrate microsite assemblages (exclusive of mammals) from the Foremost and Oldman Formations of the Judith River Group (Campanian) of southeastern Alberta: An illustrated guide, p. 1-25. Provincial Museum of Alberta Natural History Occasional Paper, 25. https://doi.org/10.5962/bhl.title.115853

Rauhut, O. WM, López-Arbarello, A., Röper, M., and Rothgaenger, M. 2017. Vertebrate fossils from the Kimmeridgian of Brunn: the oldest fauna from the Solnhofen Archipelago (Late Jurassic, Bavaria, Germany). Zitteliana, 89:305-329. https://doi.org/10.5282/ubm/epub.40470

Reeside, J.B. 1955. Revised interpretation of the Cretaceous section of the Vermilion Creek, Moffat County, Colorado, 85-88. 10th Annual Field Conference Guidebook, Wyoming Geological Association.

Rogers, R.R. 2005. Fine-grained debris flows and extraordinary vertebrate burials in the Late Cretaceous of Madagascar. Geology, 33:297-300. https://doi.org/10.1130/g21036.1

Rogers, R.R., Sampson, S.D., and Roberts, E.M. 1997. Taphonomy of semi-arid depositional setting: a case study from the subtropical Late Cretaceous of Madagascar. Journal of Vertebrate Paleontology, 17 (supplement):71A.

Rogers, R.R., Hartman, J.H., and Krause, D.W. 2000. Stratigraphic analysis of Upper Cretaceous rocks in the Mahajanga Basin, Northwestern Madagascar: implications for ancient and modern faunas. Journal of Geology, 108:275-301.

Rogers, R.R., Krause, D.W., Kast, S.C., Marshall, M.S., Rahantarisoa, L., Robins, C.R., and Sertich, J.J. 2013. A new, richly fossiliferous member comprised of tidal deposits in the Upper Cretaceous Maevarano Formation, northwestern Madagascar. Cretaceous Research, 44:1229. https://doi.org/10.1016/j.cretres.2013.03.008

Russell, L.S. and Landes, R.W. 1937. Geology of the Southern Alberta Plains. Part II. Paleontology of the marine formations of the Montana Group. Geological Survey of Canada Memoir, 221:129-217.

Sahni, A. 1972. The vertebrate fauna of the Judith River Formation, Montana. Bulletin of the American Museum of Natural History, 6:321-412.

Sauvage, H.E. 1875. Essai sur la fauna ichthyologique de la période Liasique suivi d'une notice sur les poissons du Lias de Vassy, deuxième mémoire. Bibliothèque de l'École des Hautes Études, Section des Sciences Naturelles, 14:1-24.

Schwimmer, D.R. 1986. Late Cretaceous fossils from the Blufftown Formation (Campanian) in western Georgia. The Mosasaur, 3:109-123.

Scopoli, G.A. 1777. Introductio ad historiam naturalem sistema genera lapidum, plantarum et animulium, Prague. https://doi.org/10.5962/bhl.title.10827

Scotese, C. 2014. Atlas of Late Cretaceous Paleogeographic Maps, PALEOMAP Atlas for ArcGIS, volume 2, The Cretaceous, Maps 16 - 22, Mollweide Projection. PALEOMAP Project, Evanston, IL. http://doi.org/10.13140/2.1.4691.3284 
Sohl, N.F. and Koch, C.F. 1983. Upper Cretaceous (Maestrichtian) Mollusca from the Haustator bilira zone in the East Gulf Coastal Plain. United States Geological Survey, 83-451:1-238. https://doi.org/10.3133/ofr83451

Stephenson, L.W. 1941. The larger invertebrate fossils of the Navarro group of Texas. The University of Texas, Publication 4101:625.

Storer, J. 1993. Additions to the mammalian paleofauna of Saskatchewan. Modern Geology, 18:475-487.

Storey, M., Mahoney, J., Saunders, A., Duncan, R., Kelley, S., and Coffin, M. 1995. Timing of hot spot-related volcanism and the breakup of Madagascar and India. Science, 267:852-855. https://doi.org/10.1126/science.267.5199.852

Vullo, R., Bernárdez, E., and Buscalioni, A.D. 2009. Vertebrates from the middle?-late Cenomanian La Cabaña Formation (Asturias, northern Spain): Palaeoenvironmental and palaeobiogeographic implications. Palaeogeography, Palaeoclimatology, Palaeoecology, 276(1-4):120-129. https://doi.org/10.1016/j.palaeo.2009.03.004

Wade, B. 1926. The fauna of the Ripley Formation on Coon Creek, Tennessee. United States Geological Survey, Professional Paper, 137:1-272. https://doi.org/10.3133/pp137

Wiley, E.O. and Johnson, G.D. 2010. A teleost classification based on monophyletic groups., p. 123-182. In Nelson, J.S., Schultze, H.-P., and Wilson, M.V.H. (eds.), Origin and Phylogenetic Interrelationships of Teleosts. Verlag Dr. Friedrich Pfeil, München.

Zangerl, R. 1948. The vertebrate fauna of the Selma formation of Alabama. Part II. The Pleurodiran turtles. Fieldiana Geology Memoirs, 3(1/2):17-56. 